\title{
Evaluating Green Performance of Suppliers via Analytic Network Process and TOPSIS
}

\author{
Gülşen Akman and Hamit Pışkın \\ Department of Industrial Engineering, Faculty of Engineering, Kocaeli University, 41380 Kocaeli, Turkey \\ Correspondence should be addressed to Gülşen Akman; akmang@kocaeli.edu.tr
}

Received 15 August 2012; Revised 29 January 2013; Accepted 25 February 2013

Academic Editor: C. K. Kwong

Copyright (C) 2013 G. Akman and H. Pışkın. This is an open access article distributed under the Creative Commons Attribution License, which permits unrestricted use, distribution, and reproduction in any medium, provided the original work is properly cited.

\begin{abstract}
Developments in environmental issues in the last few years have been forcing manufacturing companies to improve their environmental performances. Many firms developed integrated relationships with their suppliers to increase their environmental performance and to decrease their hazardous effects on the environment. Then, selecting suitable and green suppliers in the supply chain has become a key strategic consideration. A performance evaluation system for green suppliers is necessary to determine the suitability of suppliers to cooperate with the firm. Therefore, in this study, a model for evaluating green performance of suppliers is proposed, and a hybrid multicriteria decision making model is developed in order to evaluate green performance of the suppliers. The analytical network process technique is applied to handle the relationships and dependence of selection criteria and subcriteria and determine weights of the criteria. The technique for order preference by similarity to ideal solution is used to sequence the suppliers for ideal solution of the suppliers' green performance evaluation problem. After a comprehensive literature survey, evaluation criteria of green performance for suppliers are determined. Finally, green performance of 18 suppliers of an automobile company was evaluated by this model. These 18 suppliers manufacture chassis and its components.
\end{abstract}

\section{Introduction}

In recent years, because of growing worldwide awareness of environmental protection, increasing government regulations, and stronger public awareness in environmental protection, firms today cannot disregard environmental issues, and they have to pay attention to environmental issues in order to survive in the global market [1]. Therefore, in the world, there is a growing interest in the green supply chain management (GSCM), and the green issue has become more and more critical in supply chain management (SCM) [2]. Over the last decade linking supply chain activities and environmental issues such as green purchasing, reverse logistics, product stewardship, and design for the environment have been a topic of interest among many manufacturing organizations [3]. In order to decrease hazardous environmental effects, firms have been forced to improve their environmental issues like decreasing hazardous impacts of their products, their manufacturing processes, logistics processes, and so forth [4].

Environmental performance of a company can be determined by its own environmental efforts and environmental performance of its suppliers. For manufacturing industries, green manufacturing (i.e., manufacturing is environmentally responsible) and concerned processes need green supply chain (GSC) and studying suppliers with green abilities [5]. Therefore companies have to establish close and integrated relationships with their supplier to develop their environmental performance. They have to evaluate green performance of their suppliers. Thus there is an increasing need of a performance evaluation system for green suppliers to determine the suitability of suppliers to cooperate with the firm [6].

In the literature, while there are too many studies about supplier selection and evaluation, the number of studies about green supplier selection and evaluation is very limited. 
Therefore this study was performed in the area of green supplier performance. Our contributions from this study include (1) modeling the decision problem within the context of a GSCM decision, and (2) evaluation of supplier performance by the view point of environmental issues.

In the green supply chain literature, various techniques are used to evaluate and select green suppliers, such as rating system [4], analytic hierarchy process (AHP) [7], fuzzy AHP $[8,9]$, a hybrid fuzzy analytic network process (ANP) and fuzzy Preference Ranking Organization method for enrichment evaluations (PROTMETHEE) [10], fuzzy extended AHP [1], fuzzy goal programming [11], artificial neural network, data envelopment analysis and analytic netwok process (ANP) [2], Rough set theory [12], fuzzy Technique for Order Preference by similarity to ideal solution (TOPSIS) [13], an integrated model of fuzzy decision making trial and evaluation laboratory (DEMATEL), ANP, TOPSIS [5], a greybased DEMATEL approach [14], Grey approach [15], fuzzy AHP and fuzzy multiobjective linear programming [16].

Because there are both qualitative and quantitative factors that influence the evaluation and selection of green suppliers, evaluation and selection problem of green supplier is a multicriteria decision making (MCDM) problem. Thus there is a need to employ MCDM techniques to tackle green supplier selection problem appropriately. Firstly, ANP technique [17] is applied to handle the relationships and dependence of selection criteria and subcriteria and to determine weights of criteria. Then, TOPSIS technique is used to sequence the suppliers for ideal solution of the supplier evaluation problem.

The paper is organized as follows. The paper begins with the literature research about GSCM. Then, after a brief literature review of methodologies used evaluation of supplier's environmental performance and selection of green supplier are examined to develop a structure for evaluating green supplier performance and selecting green suppliers. The next section illustrates the proposed green supplier evaluation and selection methodology through the case of an automobile company in Turkey. The paper finishes by a discussion section.

\section{Literature Review}

2.1. Green Supply Chain. Green et al. [18] defined green supply as "the way in which innovations in SCM and industrial purchasing may be considered in the context of the environment." Srivastava [19] defined GSCM as "integrating environmental thinking into supply chain management, including product design, material sourcing and selection, manufacturing processes, delivery of the final product to the consumers and end-of-life management of the product after its useful life." Also, many researchers have defined a GSCM in various manners using different terms [20]. GSCM can be defined as integrating environmental issues into supply chain management. Originally, GSCM was bounded to purchasing issues. Hervani et al. [21] defined GSCM as integrating suppliers into environmental management processes. Rettab and Ben Brik [22] defined the GSC as a managerial approach that seeks to minimize a product or service's environmental effect. The bottom line of these definitions is the same, that is, "environment". GSCM contains the activities such as waste reduction, recycling, reuse, and the substitution of materials [23], and it includes green purchasing, green manufacturing and material management, green distribution and marketing, and reverse logistics [24].

According to Narasimhan and Carter [23], GSCM includes "the purchasing function's involvement in activities that include reduction, recycling, reuse and the substitution of materials." The most common GSCM practices are to evaluate the environmental performance of suppliers, to require suppliers to accept measures providing environmental quality of their supplied products and to evaluate the cost of waste in their manufacturing processes [7]. However, GSCM practices also extend to the entire value chain (from supplier to consumer) when organizations inform buyers of ways to reduce their impacts on the natural environment [25].

Hall [26] investigated the circumstances under which "environmental supply chain dynamics" emerge. He argued that environmental supply chain dynamics emerge when environmental pressures are synthesized with supply chain pressures which have had considerable influence on the supply base on the strength of case studies in the British and Japanese food retail sector and the British aerospace industry. Zhu et al. [27] expressed that "range of GSCM changes from green purchasing (GP) to integrated life-cycle management supply chains flowing from supplier, through to manufacturer, customer, and closing the loop with reverse logistics."

According to Vachon and Klassen [3], suppliers, manufacturers, and customers should collaborate to reduce hazardous environmental effects from manufacturing processes and products.

2.2. Evaluation of Green Supplier Performance. Supplier evaluation process is an important element in supplier-based manufacturing and SCM has been gaining attention in both the academic literature and industrial practice. The supplier selection decision is one of the critical and important issues in SCM for many organizations to help maintain a strategically competitive position [28]. It becomes one of the most important components of production and operations management for many organizations. Supplier selection and evaluation process is the process by which the company identifies, evaluates, and contracts suppliers.

Measuring and understanding supplier performance is crucial to provide a well-functioning supply chain and to develop competitive position of a company. The goal of the supplier evaluation is to develop the performance of key suppliers [29]. Companies have some advantages through evaluating their suppliers. They have better visibility into supplier performance, decrease risk, reduce order cycle times and inventory, and thus increase competitive advantage and coordinate practices between themselves and their suppliers [29].

In the last two decades, there is increasing attention to evaluate suppliers' green performance. There are lots of studies related this topics in the literature. A detailed literature search was performed about the concepts of GSC. 


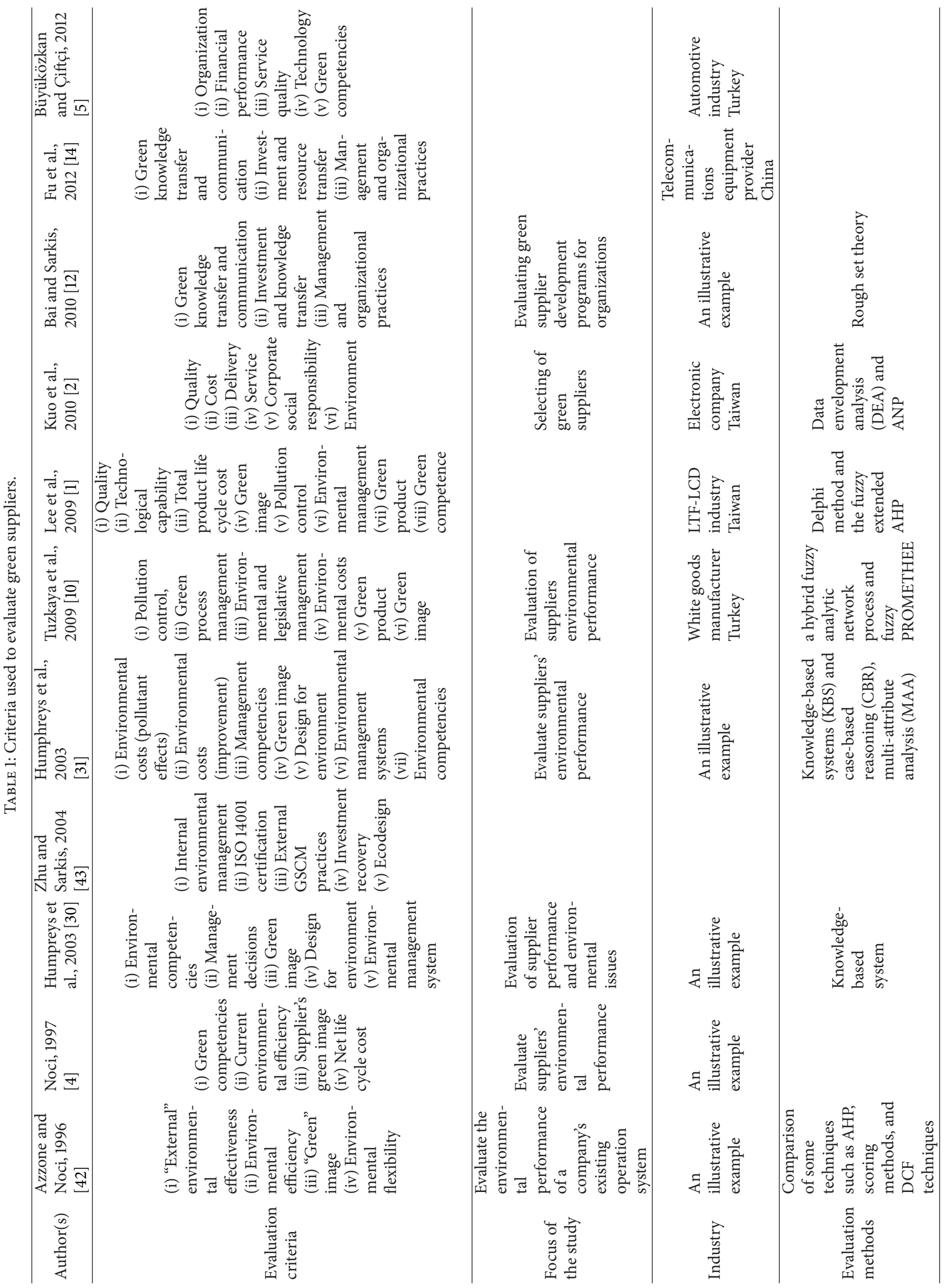


TABLE 2: Factors and subfactors for ANP.

\begin{tabular}{|c|c|}
\hline Criteria & Definition \\
\hline $\mathrm{ECl}$ & $\begin{array}{l}\text { To respond in time to product or process } \\
\text { modifications when customer demands from } \\
\text { supplier to reduce supplier's environmental } \\
\text { impact }\end{array}$ \\
\hline EC2 & $\begin{array}{l}\text { Capabilities related with clean production } \\
\text { technology }\end{array}$ \\
\hline EC3 & $\begin{array}{l}\text { Materials used in the supplied components that } \\
\text { reduce the impact on natural resources }\end{array}$ \\
\hline EC4 & $\begin{array}{l}\text { Ability to alter process and products for reducing } \\
\text { the impact on natural resources }\end{array}$ \\
\hline ECO1 & $\begin{array}{l}\text { Cooperation with customers for ecodesign to } \\
\text { develop green products }\end{array}$ \\
\hline $\mathrm{ECO} 2$ & $\begin{array}{l}\text { Cooperation with customers for decreasing } \\
\text { energy usage in supplied products and their } \\
\text { manufacturing process, that is, cleaner production }\end{array}$ \\
\hline ECO3 & $\begin{array}{l}\text { Cooperation with customers for green logistics } \\
\text { and transportation }\end{array}$ \\
\hline $\mathrm{ECO} 4$ & $\begin{array}{l}\text { Cooperation with customer about environment } \\
\text { management system and technologies }\end{array}$ \\
\hline EMS1 & Environment-related certificates (i.e., ISO 14000) \\
\hline EMS2 & $\begin{array}{l}\text { Continuous monitoring and compliance with } \\
\text { related environmental legislation and legal } \\
\text { regulations }\end{array}$ \\
\hline GP1 & $\begin{array}{l}\text { Design of products for reuse, recycle, and } \\
\text { recovery of materials, component parts }\end{array}$ \\
\hline GP2 & $\begin{array}{l}\text { Design of products for reduced consumption of } \\
\text { materials/energy }\end{array}$ \\
\hline GP3 & $\begin{array}{l}\text { Design of products to avoid or reduce use of } \\
\text { hazardous products and their manufacturing } \\
\text { process }\end{array}$ \\
\hline $\mathrm{PC} 1$ & $\begin{array}{l}\text { In order to prevent existence air pollution, } \\
\text { air-pollution-control systems }\end{array}$ \\
\hline PC2 & $\begin{array}{l}\text { Decrease water consumption and sufficiency of } \\
\text { water refining plants }\end{array}$ \\
\hline PC3 & Evaluation and disposal system for solid wastes \\
\hline PC4 & $\begin{array}{l}\text { Disposal of hazardous wastes according to legal } \\
\text { regulations }\end{array}$ \\
\hline
\end{tabular}

Some concepts and elements were found as the basis for a decision framework for evaluating and prioritizing supplier by the company that would help to select green suppliers. Some of these concepts and elements are summarized as follows in Table 1.

Noci [4] designed a conceptual approach that firstly identifies measures for assessing a supplier's environmental performance and, secondly, suggests effective techniques for developing the supplier selection procedure according to an environmental view point. Humpreys et al. [30] developed a framework from an analysis of environmental management practices in a number of companies along with a through literature survey. Then they outlined how the most important parts of the framework were computerized using knowledge based systems (KBS) techniques with an evaluation of the system implemented in a multinational company. Humphreys et al. [31] developed a KBS which integrates environmental factors into the supplier selection process. The system employs both case-based reasoning (CBR) and decision support components including multiattribute analysis (MAA).

Hsu and $\mathrm{Hu}$ [32] proposed an ANP approach to incorporate the issue of hazardous substance management (HSM) into supplier selection. They presented an illustrative example in an electronics company to demonstrate how they select a most appropriate supplier in accordance with the requirements of hazardous substance for environmental regulations. Lee et al. [1] proposed a model to select the factors for evaluating green suppliers and to evaluate the performance of suppliers. First they applied the Delphi method to select the most important subcriteria for traditional suppliers and for green suppliers. Then, they developed a fuzzy extended AHP model to evaluate green suppliers for a TFT-LCD manufacturer in Taiwan. Tsai and Hung [11] proposed a fuzzy goal programming (FGP) approach that integrates activitybased costing $(\mathrm{ABC})$ and performance evaluation in a valuechain structure for optimal green supplier selection and flow allocation. Then they provide an illustrative example via a green supply chain of a mobile phone.

Tuzkaya et al. [10] evaluated the environmental performance of suppliers with a hybrid fuzzy multicriteria decision approach: fuzzy ANP and fuzzy PROMETHEE methodology. They used evaluation criteria such as pollution control, green process management, environmental and legislative management, environmental costs, green product, and green image. To foster the better understanding and the validation of the proposed methodology, they presented a real-life case study from a white goods manufacturer of Turkey.

Bai and Sarkis [12] developed a formal model using rough set theory to investigate the relationships between organizational attributes, supplier development program, involvement attributes, and performance outcomes. The performance outcomes focused on environmental and business dimensions. Their methodology generated decision rules relating the various attributes to the performance outcomes. Kuo et al. [2] proposed a green supplier selection model which integrates artificial neural network (ANN) and two multi-attribute decision analysis (MADA) methods: data envelopment analysis (DEA) and ANP. The model is called ANN-MADA hybrid method.

Fu et al. [14] proposed a formal structured managerial approach for organizations to help evaluate the influence of relationships amongst green supplier development programs (GSDPs). Utilizing GSDP categorizations they acquire multifunctional managerial inputs within a telecommunication systems provider to evaluate the GSDPs. Büyüközkan and Çiftçi [5] examined GSCM and GSCM capability dimensions to propose an evaluation framework for green suppliers and used a fuzzy hybrid MCDM model based on fuzzy DEMATEL, fuzzy ANP, and fuzzy TOPSIS techniques in order to evaluate green suppliers. Also they proposed application of the methodology for green supplier evaluation in a specific company in the automotive industry in Turkey. The major five evaluation criteria for green suppliers are organization, financial performance, service quality, technology, and green competencies. Green competencies criteria contain social 


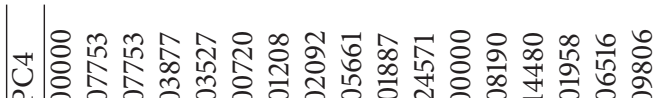

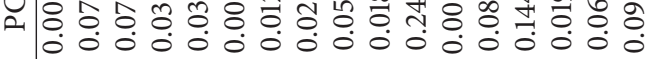

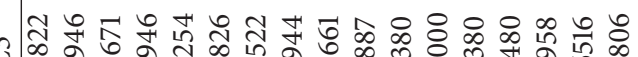

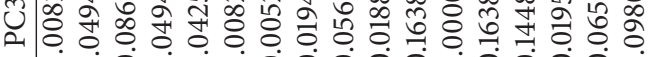

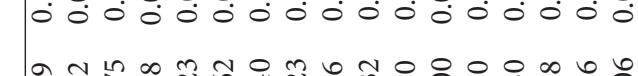

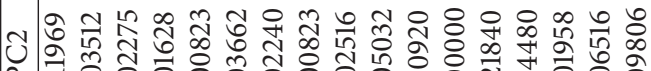

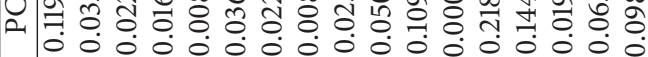
요ㅇㅠㅛ

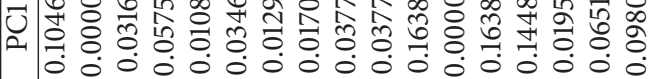
范官

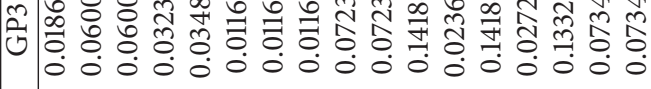

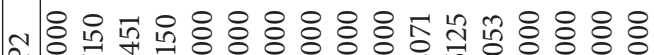

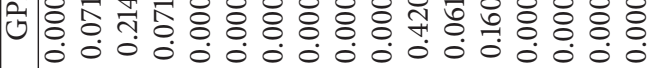
m m m $\infty$ m

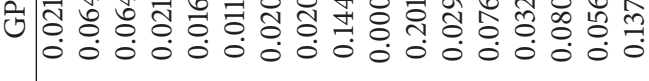
N

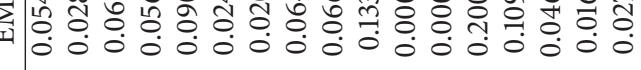

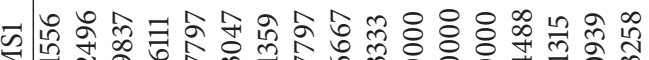
I

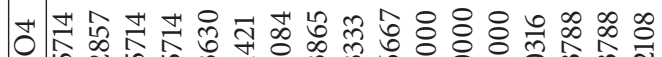

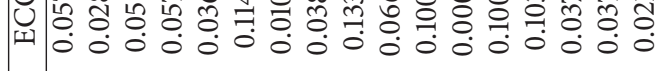

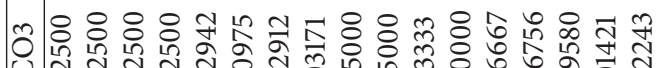

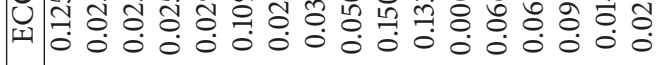

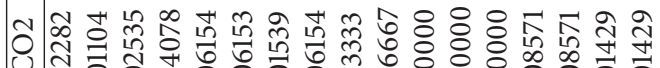
壮

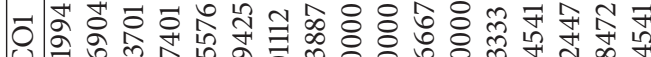
任

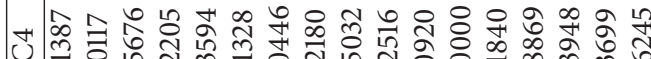
|

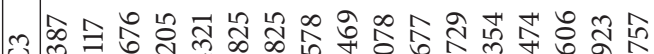
|

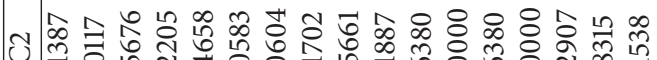
训|

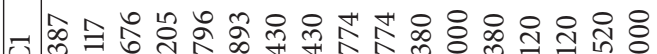

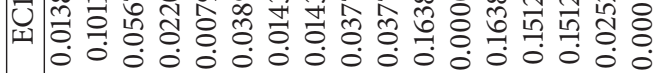

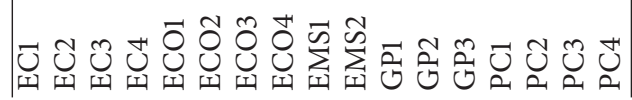


responsibility, cleaner/environmental production and technologies, and environmental management system.

\section{Proposed Green Supplier Evaluation Framework}

This study proposes a hybrid approach based on the ANP and TOPSIS methodologies to evaluate and select suppliers in the context of GSCM. The general view of the proposed methodology related with green supplier evaluation and selection is shown in Figure 1. ANP technique is applied to handle the relationships and dependence of selection criteria and subcriteria. TOPSIS technique is applied to sequence the suppliers for ideal solution of the green supplier performance evaluation problem.

3.1. Analytical Network Process (ANP). The ANP developed by Saaty, and it provides a way to input judgments and measurements to derive ratio scale priorities for the distribution of influence among the factors and groups of factors in the decision [33]. ANP is an extension of AHP. In reality, the factors within the hierarchy are often interdependent. The ANP method presents the network relationship between factors and between groups of factors and computes the relative weightings of each factor. The result of these computations constructs a supermatrix. Finally, after computing the relationship of the supermatrix and the comprehensive evaluations, it is possible to derive the interdependence of each evaluation factor and options and the weighting of priorities. Factors/alternatives are sequenced according to higher the priority weightings. In this way, it is possible to select the most appropriate alternative [34]. See Tsai and Chou [34], Lin et al. [35], and Saaty [17, 33] for further details.

\subsection{Technique for Order Preference by Similarity to Ideal} Solution (TOPSIS). The TOPSIS method is based on the idea that the chosen alternative should have the shortest distance from the positive ideal solution, and the farthest distance from the negative ideal solution [36].

First a decision matrix is established for the ranking. The normalized decision matrix $R\left(=\left[r_{i j}\right]\right)$ is calculated. Then the weighted normalized decision matrix is calculated by multiplying the normalized decision matrix by its associated weights. After the positive ideal solutions (PIS) and negative ideal solutions (NIS) are determined, respectively, the separation measures are calculated using the $m$-dimensional Euclidean distance. Finally, the relative closeness to the idea solution $\left(C_{i}\right)$ is calculated and the alternatives are ranked in descending order. The index value of $C_{i}$ lies between 0 and 1. The larger the index value, the better the performance of the alternatives. You can see Chu et al. [37], Jahanshahloo et al. [38] for further details. The TOPSIS method will be applied to a case study, which is described in detail in the application section.

3.3. Criteria of Green Supplier Evaluation Framework. When traditional studies are investigated, there are three main criteria to evaluate and select suppliers; cost, quality, and

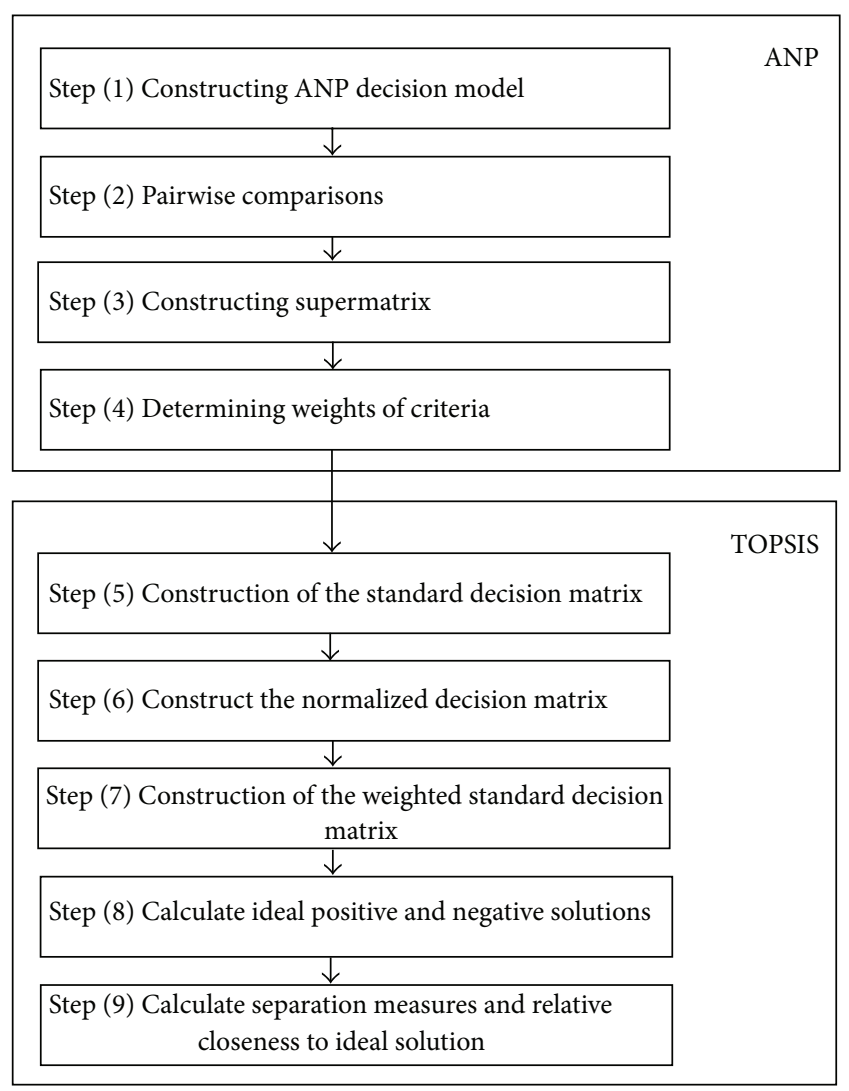

FIGURE 1: Methodology of the study.

delivery [39]. Additionally, criteria such as customer satisfaction, flexibility, and after-sales service that are used to evaluate suppliers are used [40]. An organization may use traditional selection criteria because of the organization's core processes requirements. These criteria generally cover issues such as quality, cost, delivery, capacity in terms of finance, services, and equipments, quantity, and responsiveness. Green supplier selection criteria are derived from an organizational tendency to respond to any existing trends in environmental topics related to business management and processes.

Most of the studies in the literature about evaluation of green supplier performance integrates environmental criteria into traditional supplier evaluation criteria. They utilize traditional evaluation criteria and environmental criteria together. For example Humpreys et al. [30], Büyüközkan and Çiftçi [5], Kuo et al. [2], and Lee et al. [1] integrated environmental criteria into supplier selection process and used environmental criteria and classical supplier development criteria together. In the literature, there is in only one study using environmental criteria for evaluating supplier performance, Shenc et al. [41]. Because of expanding studies about this area and making contribution to the literature, in this study we use only environmental criteria to evaluate supplier performance in order to develop environmental performance of the main company.

In this study, we used qualitative environmental criteria, and five evaluation criteria were determined to evaluate 


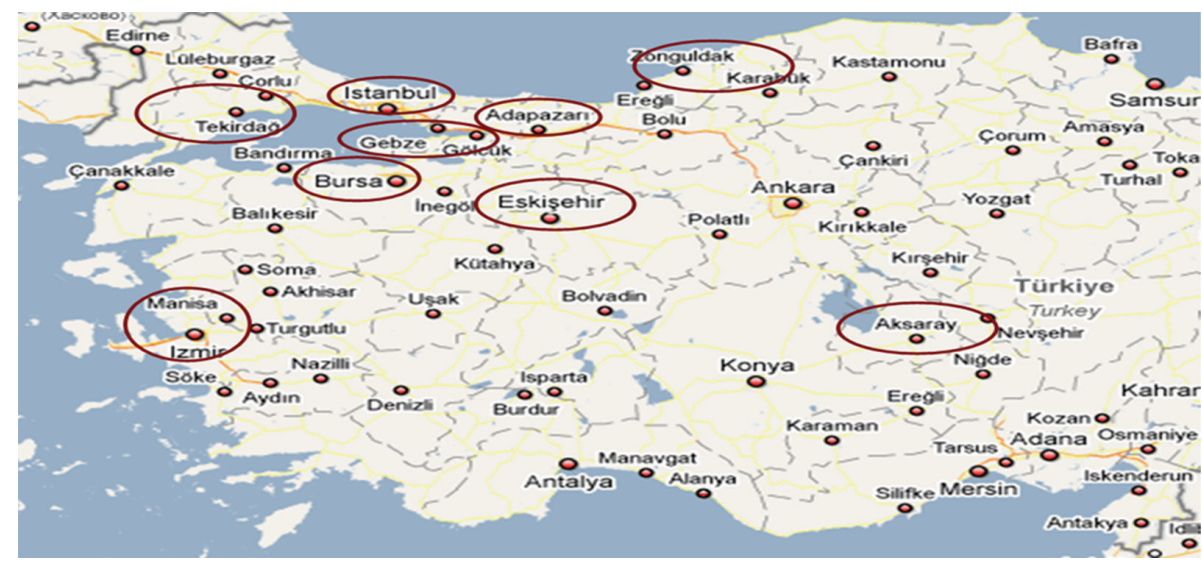

Figure 2: Distribution of the local suppliers.

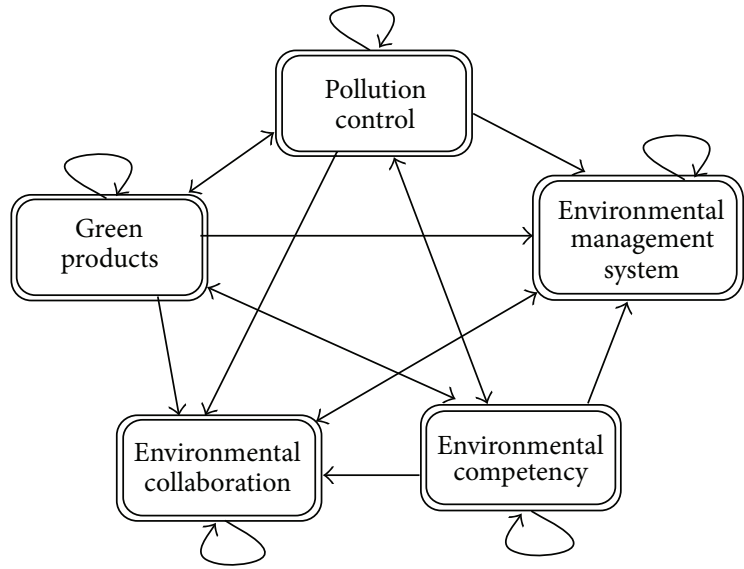

FIGURE 3: ANP hierarchy for the green supplier evaluation.

environmental performance of suppliers. These are environmental technologies and pollution control (PC), environmental management system (EMS), green products (GP), environmental collaboration (ECO), environmental competency (EC).

\section{Application}

4.1. Application of the Proposed Supplier Evaluation Methodology. The application was performed in the company which is a multinational company and one of the most important and biggest pioneer companies in the Turkish automobile industry. The company implements green practices at all stages of the manufacturing process. The company works with more than 60 local suppliers performing in Turkey. Distribution of the local suppliers of the company can be seen in Figure 2.

\subsection{The Computational Steps of the Proposed Integrated Framework}

Step 1 (constructing ANP decision model). ANP decision model was constructed based on opinions of five experts working in the company. This model is presented in Figure 3. The model consists of five main factors; environmental competency, environmental collaboration, environmental management system, green products, and environmental technologies and pollution control. Environmental competency contains four sub-factors (EC1, .., EC4), environmental collaboration contains four sub-factors (ECO1, ..., ECO4), environmental management system contains two sub-factors (EMS1, EMS2), green products contains three sub-factors (GP1, .., GP3), and environmental technologies and pollution control contains four sub-factors (PC1,..., PC4). These criteria are shown in Table 2.

Step 2 (pairwise comparisons). The pairwise comparisons (cluster comparisons and element comparisons) were performed using the 9-point scale of Saaty [17], where 1, 3, 5, 7 , and 9 indicate equal importance, moderate importance, strong importance, very strong importance, and extreme importance, respectively; $2,4,6$, and 8 are used for compromise between the above values. The ANP model is solved using "Super Decisions" software. All inconsistency ratios are below 0.1, which indicates acceptable levels of consistency across pairwise comparisons.

Step 3 (constructing supermatrix). In this step the unweighted supermatrix, weighted supermatrix and limit supermatrix were constructed. The unweighted supermatrix was calculated with priority vectors obtained from pairwise comparison matrices for interdependencies among the sub-factors. The unweighted supermatrix cannot reflect the normalized weights as the sum of the column values is not equal to 1. Accordingly, the unweighted matrix was transformed to the weighted supermatrix to reveal influences on a $0-1$ scale. The weighted supermatrix is presented in Table 3. Finally, the limit matrix was obtained by means of increasing the power of the weighted supermatrix. The limit matrix is presented in Table 4.

Step 4 (cetermining weights of criteria). Weights of criteria to be used in TOPSIS method are determined based on the limit matrix as shown in Table 4. 


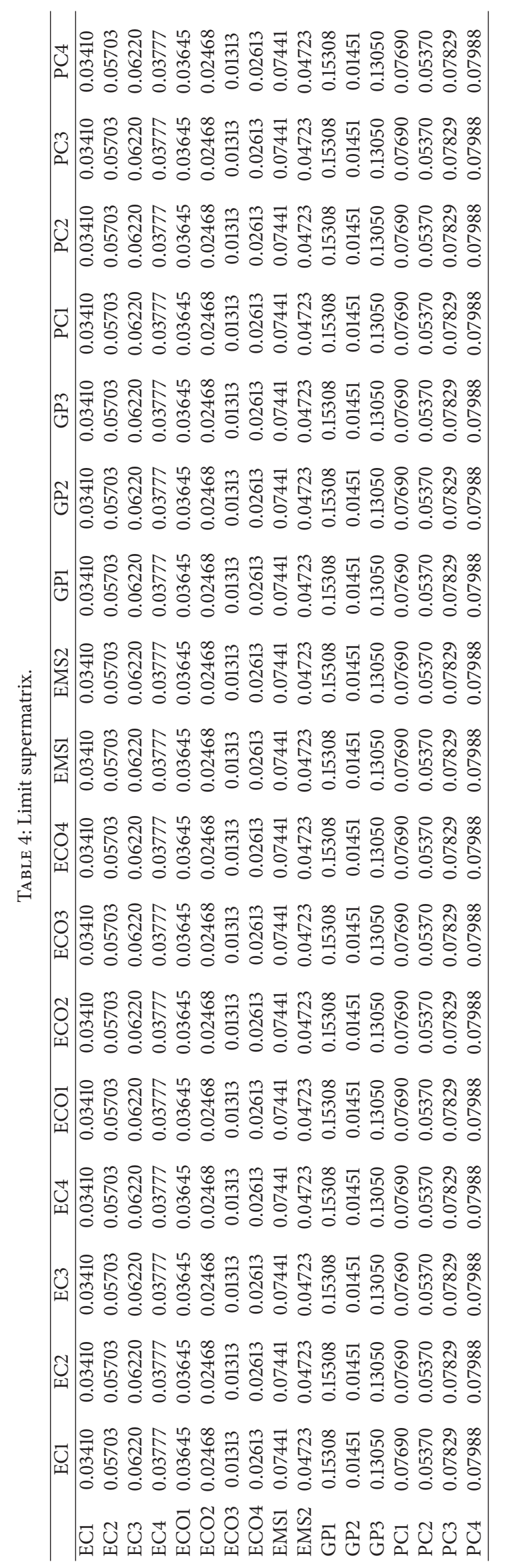


TABLE 5: Standard decision matrix.

\begin{tabular}{|c|c|c|c|c|c|c|c|c|c|c|c|c|c|c|c|c|c|}
\hline \multirow[t]{2}{*}{ Supplier } & \multicolumn{4}{|c|}{ Pollution control } & \multicolumn{2}{|c|}{$\begin{array}{l}\text { Environment } \\
\text { management } \\
\text { system }\end{array}$} & \multicolumn{3}{|c|}{ Green products } & \multicolumn{4}{|c|}{ Environmental collaboration } & \multicolumn{4}{|c|}{ Environmental competency } \\
\hline & pcl & pc2 & pc3 & pc4 & ems1 & ems2 & gp1 & gp2 & gp3 & ecol & eco2 & eco3 & eco 4 & ecl & ec2 & ec3 & ec4 \\
\hline S1 & 6.33 & 5.00 & 6.67 & 6.00 & 6.00 & 4.67 & 6.33 & 5.00 & 5.33 & 5.67 & 6.33 & 4.33 & 5.67 & 5.33 & 6.33 & 5.67 & 5.67 \\
\hline S2 & 4.75 & 4.50 & 5.25 & 6.25 & 4.00 & 5.00 & 5.75 & 4.00 & 5.50 & 4.75 & 4.25 & 4.25 & 4.50 & 4.25 & 6.25 & 5.25 & 4.50 \\
\hline S3 & 5.33 & 4.67 & 5.67 & 5.67 & 5.67 & 5.33 & 5.33 & 4.33 & 5.00 & 5.67 & 5.67 & 4.33 & 5.33 & 5.67 & 6.33 & 5.67 & 5.33 \\
\hline S4 & 5.33 & 5.67 & 4.67 & 5.33 & 5.00 & 5.00 & 6.33 & 5.00 & 6.33 & 4.67 & 6.00 & 4.00 & 4.67 & 4.67 & 5.00 & 5.33 & 4.33 \\
\hline S5 & 5.50 & 5.50 & 5.00 & 5.25 & 5.00 & 5.00 & 6.00 & 6.25 & 6.00 & 5.00 & 6.25 & 3.75 & 5.00 & 5.00 & 5.50 & 5.25 & 5.00 \\
\hline S6 & 6.80 & 5.60 & 6.20 & 6.20 & 6.00 & 6.00 & 6.40 & 5.60 & 5.40 & 5.60 & 6.00 & 5.80 & 6.20 & 6.00 & 6.20 & 6.20 & 5.40 \\
\hline S7 & 5.00 & 3.33 & 4.00 & 4.33 & 3.00 & 5.67 & 4.00 & 5.67 & 3.67 & 4.33 & 3.67 & 4.00 & 4.00 & 4.00 & 4.33 & 3.67 & 3.33 \\
\hline S8 & 5.75 & 5.75 & 5.25 & 5.00 & 5.25 & 6.00 & 5.75 & 5.75 & 6.00 & 6.00 & 5.75 & 4.75 & 6.25 & 5.25 & 5.50 & 5.50 & 6.00 \\
\hline S9 & 6.00 & 4.50 & 5.00 & 4.50 & 3.50 & 5.25 & 4.75 & 5.00 & 4.25 & 4.25 & 6.00 & 5.00 & 5.00 & 5.75 & 5.25 & 4.75 & 5.50 \\
\hline S10 & 6.40 & 4.80 & 6.40 & 6.20 & 6.00 & 5.40 & 5.80 & 5.40 & 5.80 & 5.80 & 5.60 & 4.80 & 5.00 & 5.40 & 5.80 & 6.00 & 5.60 \\
\hline S11 & 5.67 & 5.67 & 5.33 & 6.67 & 5.33 & 6.33 & 6.33 & 6.00 & 6.33 & 6.00 & 6.00 & 4.67 & 6.00 & 4.33 & 6.33 & 5.67 & 5.67 \\
\hline S12 & 5.40 & 4.80 & 5.80 & 5.20 & 5.40 & 5.00 & 6.00 & 5.00 & 6.00 & 5.00 & 4.60 & 4.60 & 5.20 & 4.60 & 5.80 & 5.80 & 5.00 \\
\hline S13 & 4.33 & 3.33 & 5.67 & 6.00 & 4.00 & 4.33 & 5.67 & 5.33 & 5.33 & 4.33 & 3.33 & 3.67 & 4.00 & 4.00 & 6.00 & 5.00 & 4.00 \\
\hline S14 & 5.75 & 4.75 & 6.25 & 5.75 & 6.00 & 5.50 & 5.50 & 5.75 & 5.75 & 5.75 & 5.50 & 3.50 & 5.25 & 4.75 & 6.25 & 6.00 & 6.00 \\
\hline S15 & 6.25 & 4.75 & 6.00 & 4.25 & 6.50 & 5.50 & 5.75 & 3.75 & 5.50 & 5.50 & 5.25 & 5.00 & 6.00 & 5.50 & 6.00 & 6.00 & 4.75 \\
\hline S16 & 5.33 & 4.33 & 5.67 & 4.67 & 4.67 & 4.33 & 6.00 & 5.67 & 5.33 & 4.33 & 3.67 & 3.67 & 4.33 & 3.33 & 5.67 & 5.33 & 5.33 \\
\hline S17 & 6.50 & 5.00 & 6.00 & 5.50 & 6.50 & 5.50 & 6.00 & 6.00 & 5.00 & 4.00 & 6.50 & 3.00 & 6.00 & 6.00 & 5.00 & 6.50 & 6.50 \\
\hline S18 & 6.67 & 5.33 & 6.33 & 6.33 & 6.33 & 5.67 & 6.33 & 5.00 & 5.67 & 5.67 & 6.33 & 5.67 & 5.33 & 5.33 & 5.67 & 6.00 & 5.33 \\
\hline
\end{tabular}

Step 5 (construction of the standard decision matrix). For this, first alternatives were determined. We aimed to evaluate environmental performance of suppliers manufacturing chassis and its components. The company has 18 suppliers manufacturing chassis and its components. Suppliers were evaluated using a 1-7 scale (1-lowest performance, ..., 7highest performance) by five decision makers working in purchasing (2 members), quality (2 members), and manufacturing (1 member) departments, and mean values for each suppliers were calculated. Than initial decision matrix for TOPSIS was constructed based on these mean values as presented in Table 5.

Step 6 (construct the normalized decision matrix). In this step, the normalized decision matrix $R=\left[r_{i j}\right]$ is calculated. The normalized value $r_{i j}$ is calculated

$$
r_{i j}=\frac{f_{i j}}{\sqrt{\sum_{j=1}^{n} f_{i j}^{2}}},
$$

where $j=1, \ldots, n ; i=1, \ldots, m$. Normalized decision matrix for the evaluation of green supplier performance (GSP) problem is shown in Table 6.

Step 7 (construction of the weighted standard decision matrix). The weighted normalized decision matrix is calculated by multiplying the normalized decision matrix by its associated weights. The weighted normalized value $v_{i j}$ is calculated from (2). Here $w_{i j}$ represents the weight of the $j$ th attribute or criterion. The Weighted normalized matrix for the GSP evaluation problem is shown in Table 7:

$$
v_{i j}=w_{i j} r_{i j}
$$

Step 8 (construction of ideal positive $\left(V^{+}\right)$and ideal negative $\left(V^{-}\right)$solutions). The positive ideal solutions $\left(V^{+}\right)$and negative ideal solutions $\left(V^{-}\right)$are determined as follows:

$$
\begin{aligned}
& V^{+}=\left\{v_{i}^{+}, \ldots, v_{n}^{+}\right\}=\left\{\left(\operatorname{Max} v_{i j} \mid j \in J\right),\left(\operatorname{Min} v_{i j} \mid j \in J^{\prime}\right)\right\}, \\
& V^{-}=\left\{v_{i}^{-}, \ldots, v_{n}^{-}\right\}=\left\{\left(\operatorname{Min} v_{i j} \mid j \in J\right),\left(\operatorname{Max} v_{i j} \mid j \in J^{\prime}\right)\right\},
\end{aligned}
$$

where $V^{+}$is associated with the positive criteria and $V^{-}$is associated with the negative criteria. PIS and NIS for the GSP evaluation problem are presented in Table 7.

Step 9 (calculation of separation measures and relative closeness to ideal solution). The separation measures are calculated using the $m$-dimensional Euclidean distance. The separation measure $S_{i}^{+}$of each alternative and the separation measure $S_{i}^{-}$of each alternative are calculated, respectively, as follows:

$$
\begin{aligned}
& S_{i}^{+}=\sqrt{\sum_{j=1}^{n}\left(v_{i j}-v_{j}^{+}\right)^{2}}, \quad i=1, \ldots, m, \\
& S_{i}^{-}=\sqrt{\sum_{j=1}^{n}\left(v_{i j}-v_{j}^{-}\right)^{2}}, \quad i=1, \ldots, m .
\end{aligned}
$$


TABLE 6: Normalized decision matrix of TOPSIS.

\begin{tabular}{|c|c|c|c|c|c|c|c|c|c|c|c|c|c|c|c|c|c|}
\hline \multirow[t]{2}{*}{ Supplier } & \multicolumn{4}{|c|}{ Pollution control } & \multicolumn{2}{|c|}{$\begin{array}{l}\text { Environment } \\
\text { management } \\
\text { system }\end{array}$} & \multicolumn{3}{|c|}{ Green products } & \multicolumn{4}{|c|}{ Environmental collaboration } & \multicolumn{4}{|c|}{ Environmental competency } \\
\hline & pcl & pc2 & pc3 & pc4 & ems1 & ems2 & gp1 & gp2 & gp3 & ecol & eco2 & eco3 & eco4 & ecl & ec2 & ec3 & ec4 \\
\hline S1 & 1.114 & 1.270 & 0.789 & 1.551 & 0.455 & 1.203 & 1.239 & 0.857 & 1.298 & 1.221 & 1.038 & 1.263 & 1.228 & 0.994 & 1.506 & 0.902 & 1.199 \\
\hline S2 & 1.241 & 0.882 & 1.402 & 1.140 & 1.217 & 0.728 & 1.239 & 0.857 & 0.920 & 1.089 & 1.297 & 0.739 & 1.095 & 0.994 & 1.233 & 1.019 & 1.069 \\
\hline S3 & 0.698 & 0.714 & 0.870 & 1.237 & 0.541 & 0.836 & 1.021 & 0.549 & 0.979 & 0.765 & 0.584 & 0.711 & 0.691 & 0.631 & 1.201 & 0.874 & 0.674 \\
\hline S4 & 0.936 & 0.796 & 0.444 & 0.445 & 0.475 & 0.754 & 0.626 & 0.695 & 0.655 & 0.477 & 0.808 & 0.416 & 0.480 & 0.788 & 0.555 & 0.642 & 0.602 \\
\hline S5 & 0.880 & 0.768 & 1.013 & 1.017 & 1.086 & 0.951 & 0.879 & 0.644 & 0.809 & 1.089 & 1.038 & 0.739 & 0.970 & 1.122 & 1.233 & 1.019 & 0.947 \\
\hline S6 & 0.880 & 1.132 & 0.687 & 0.900 & 0.845 & 0.836 & 1.239 & 0.857 & 1.298 & 0.739 & 1.164 & 0.630 & 0.743 & 0.761 & 0.769 & 0.902 & 0.625 \\
\hline S7 & 0.495 & 0.474 & 1.136 & 1.140 & 0.455 & 0.628 & 0.992 & 0.644 & 1.039 & 0.543 & 0.359 & 0.437 & 0.379 & 0.248 & 0.987 & 0.793 & 0.625 \\
\hline S8 & 1.375 & 0.768 & 1.402 & 1.407 & 1.086 & 0.836 & 1.373 & 1.524 & 1.165 & 1.089 & 1.164 & 1.263 & 0.970 & 0.994 & 1.107 & 1.019 & 0.947 \\
\hline S9 & 1.241 & 1.132 & 1.136 & 1.140 & 1.503 & 1.203 & 1.373 & 0.857 & 1.039 & 0.739 & 1.164 & 0.857 & 1.228 & 1.258 & 0.874 & 1.410 & 1.199 \\
\hline S10 & 0.559 & 0.714 & 1.043 & 0.873 & 0.541 & 0.754 & 1.112 & 1.449 & 1.165 & 0.848 & 0.655 & 0.482 & 0.418 & 0.369 & 1.016 & 0.960 & 0.918 \\
\hline S11 & 0.936 & 1.067 & 0.789 & 0.873 & 0.845 & 0.836 & 1.112 & 1.340 & 1.165 & 0.848 & 1.263 & 0.553 & 0.853 & 0.873 & 0.930 & 0.874 & 0.833 \\
\hline $\mathrm{S} 12$ & 1.430 & 1.106 & 1.213 & 1.217 & 1.217 & 1.203 & 1.265 & 1.076 & 0.943 & 1.064 & 1.164 & 1.324 & 1.311 & 1.258 & 1.182 & 1.220 & 0.971 \\
\hline S13 & 0.773 & 0.392 & 0.505 & 0.594 & 0.304 & 1.073 & 0.494 & 1.101 & 0.435 & 0.637 & 0.435 & 0.630 & 0.546 & 0.559 & 0.577 & 0.427 & 0.370 \\
\hline S14 & 1.023 & 1.166 & 0.870 & 0.791 & 0.932 & 1.203 & 1.021 & 1.134 & 1.165 & 1.221 & 1.069 & 0.888 & 1.332 & 0.963 & 0.930 & 0.960 & 1.199 \\
\hline S15 & 1.241 & 1.003 & 1.266 & 1.017 & 1.356 & 1.203 & 0.673 & 0.747 & 0.809 & 1.360 & 1.164 & 0.630 & 0.970 & 1.122 & 1.233 & 1.273 & 1.480 \\
\hline S16 & 1.114 & 0.714 & 0.789 & 0.641 & 0.414 & 0.921 & 0.697 & 0.857 & 0.584 & 0.613 & 1.164 & 0.984 & 0.853 & 1.155 & 0.847 & 0.716 & 1.007 \\
\hline S17 & 1.267 & 0.812 & 1.293 & 1.217 & 1.217 & 0.975 & 1.039 & 1.000 & 1.088 & 1.141 & 1.014 & 0.907 & 0.853 & 1.019 & 1.034 & 1.142 & 1.044 \\
\hline S18 & 1.023 & 1.166 & 0.955 & 0.873 & 0.685 & 0.470 & 0.935 & 1.134 & 0.892 & 0.765 & 1.164 & 0.711 & 0.940 & 1.258 & 0.930 & 0.874 & 0.674 \\
\hline
\end{tabular}

The relative closeness to the ideal solution is calculated from (7) and then alternatives are ranked in descending order, where the index value of $\bar{C}_{i}$ lies between 0 and 1 . The larger the index value, the better the performance of the alternatives:

$$
\bar{C}_{i}=\frac{S_{i}^{-}}{S_{i}^{+}+S_{i}^{-}} .
$$

Separation measures $\left(S_{i}^{+}\right.$and $\left.S_{i}^{-}\right)$and relative closeness to ideal solution $\left(\bar{C}_{i}\right)$ for GSP evaluation problem are shown in Table 8. Then classes of the suppliers (A, B, C, D) were determined according to the scale presented in Table 9.

Four of the suppliers are at "A" class, and their environmental performance are perfect. Seven of the 18 evaluated firms are at "B" class. Their environmental performances are good. But in order to have better performance they should develop their environmental issues. one of the suppliers are at "C" class. Their environmental performance is inadequate and needs improvement. They perform some activities related with environment. Five of the suppliers are at " $D$ " class. Their environmental performance is so bad. They need to improve and develop their environmental performance very urgently in order to do business with their customers.

\section{Conclusions}

The need to continuously improve the corporate performance will force firms to select and evaluate their suppliers according to their environmental performance and involve also suppliers in their environmental programs. Thus companies emphasizes the importance of methodologies which allow the purchasing team to select only environmentally efficient suppliers. In order to develop their environmental performance, firms need to work together with the suppliers which have high environmental performance, and they have to work their suppliers cooperatively.

This paper presents a framework of environmental criteria that a company can consider during their supplier selection process. This study proposes a hybrid MCDM approach to evaluate performance of green suppliers because there is an increasing need to develop GSCM practices. After a comprehensive literature research and with the validation of industrial experts, possible green supplier evaluation criteria were defined and an evaluation model was developed. The proposed model was applied in an automobile company which is one of the best companies considering environmental issues in Turkey. In this study, 18 suppliers of the company that are manufacturing chassis and components were evaluated by a model that integrates ANP and TOPSIS into the context of green performance. Furthermore, TOPSIS method was used to sequence the suppliers for ideal solution of this problem efficiently.

Also this study has some limitations. One of the limitations of the study is that we use only qualitative factors to evaluate suppliers' environmental performance. In future studies, evaluation criteria should be expanded including qualitative environmental factors for example carbon footprint and quantity of emissions, and so forth.

This research suggests further studies in order to extend the scope of this study. This study can be extended to 
TABLE 7: Weighted matrix.

\begin{tabular}{|c|c|c|c|c|c|c|c|c|c|c|c|c|c|c|c|c|c|}
\hline \multirow[t]{2}{*}{ Supplier } & \multicolumn{4}{|c|}{ Pollution control } & \multicolumn{2}{|c|}{$\begin{array}{l}\text { Environment } \\
\text { management } \\
\text { system }\end{array}$} & \multicolumn{3}{|c|}{ Green products } & \multicolumn{4}{|c|}{ Environmental collaboration } & \multicolumn{4}{|c|}{ Environmental competency } \\
\hline & $\mathrm{pcl}$ & pc2 & pc3 & pc4 & ems1 & ems2 & gp1 & gp2 & gp3 & ecol & eco2 & eco3 & eco 4 & ecl & ec2 & ec3 & ec4 \\
\hline S1 & 0.038 & 0.072 & 0.049 & 0.059 & 0.017 & 0.030 & 0.016 & 0.022 & 0.097 & 0.058 & 0.159 & 0.018 & 0.160 & 0.076 & 0.081 & 0.071 & 0.096 \\
\hline S2 & 0.042 & 0.050 & 0.087 & 0.043 & 0.044 & 0.018 & 0.016 & 0.022 & 0.068 & 0.051 & 0.199 & 0.011 & 0.143 & 0.076 & 0.066 & 0.080 & 0.085 \\
\hline S3 & 0.024 & 0.041 & 0.054 & 0.047 & 0.020 & 0.021 & 0.013 & 0.014 & 0.073 & 0.036 & 0.089 & 0.010 & 0.090 & 0.049 & 0.064 & 0.068 & 0.054 \\
\hline S4 & 0.032 & 0.045 & 0.028 & 0.017 & 0.017 & 0.019 & 0.008 & 0.018 & 0.049 & 0.023 & 0.124 & 0.006 & 0.063 & 0.061 & 0.030 & 0.050 & 0.048 \\
\hline S5 & 0.030 & 0.044 & 0.063 & 0.038 & 0.040 & 0.023 & 0.012 & 0.017 & 0.060 & 0.051 & 0.159 & 0.011 & 0.127 & 0.086 & 0.066 & 0.080 & 0.076 \\
\hline S6 & 0.030 & 0.065 & 0.043 & 0.034 & 0.031 & 0.021 & 0.016 & 0.022 & 0.097 & 0.035 & 0.178 & 0.009 & 0.097 & 0.059 & 0.041 & 0.071 & 0.050 \\
\hline S7 & 0.017 & 0.027 & 0.071 & 0.043 & 0.017 & 0.015 & 0.013 & 0.017 & 0.077 & 0.026 & 0.055 & 0.006 & 0.049 & 0.019 & 0.053 & 0.062 & 0.050 \\
\hline S8 & 0.047 & 0.044 & 0.087 & 0.053 & 0.040 & 0.021 & 0.018 & 0.040 & 0.087 & 0.051 & 0.178 & 0.018 & 0.127 & 0.076 & 0.059 & 0.080 & 0.076 \\
\hline S9 & 0.042 & 0.065 & 0.071 & 0.043 & 0.055 & 0.030 & 0.018 & 0.022 & 0.077 & 0.035 & 0.178 & 0.012 & 0.160 & 0.097 & 0.047 & 0.110 & 0.096 \\
\hline S10 & 0.019 & 0.041 & 0.065 & 0.033 & 0.020 & 0.019 & 0.015 & 0.038 & 0.087 & 0.040 & 0.100 & 0.007 & 0.055 & 0.028 & 0.055 & 0.075 & 0.073 \\
\hline S11 & 0.032 & 0.061 & 0.049 & 0.033 & 0.031 & 0.021 & 0.015 & 0.035 & 0.087 & 0.040 & 0.193 & 0.008 & 0.111 & 0.067 & 0.050 & 0.068 & 0.067 \\
\hline $\mathrm{S} 12$ & 0.049 & 0.063 & 0.075 & 0.046 & 0.044 & 0.030 & 0.017 & 0.028 & 0.070 & 0.050 & 0.178 & 0.019 & 0.171 & 0.097 & 0.063 & 0.095 & 0.078 \\
\hline S13 & 0.026 & 0.022 & 0.031 & 0.022 & 0.011 & 0.026 & 0.006 & 0.029 & 0.032 & 0.030 & 0.067 & 0.009 & 0.071 & 0.043 & 0.031 & 0.033 & 0.030 \\
\hline S14 & 0.035 & 0.066 & 0.054 & 0.030 & 0.034 & 0.030 & 0.013 & 0.030 & 0.087 & 0.058 & 0.164 & 0.013 & 0.174 & 0.074 & 0.050 & 0.075 & 0.096 \\
\hline S15 & 0.042 & 0.057 & 0.079 & 0.038 & 0.049 & 0.030 & 0.009 & 0.020 & 0.060 & 0.064 & 0.178 & 0.009 & 0.127 & 0.086 & 0.066 & 0.100 & 0.118 \\
\hline S16 & 0.038 & 0.041 & 0.049 & 0.024 & 0.015 & 0.023 & 0.009 & 0.022 & 0.043 & 0.029 & 0.178 & 0.014 & 0.111 & 0.089 & 0.046 & 0.056 & 0.080 \\
\hline S17 & 0.043 & 0.046 & 0.080 & 0.046 & 0.044 & 0.024 & 0.014 & 0.026 & 0.081 & 0.054 & 0.155 & 0.013 & 0.111 & 0.078 & 0.056 & 0.089 & 0.083 \\
\hline S18 & 0.035 & 0.066 & 0.059 & 0.033 & 0.025 & 0.012 & 0.012 & 0.030 & 0.066 & 0.036 & 0.178 & 0.010 & 0.123 & 0.097 & 0.050 & 0.068 & 0.054 \\
\hline$V^{+}$ & 0.042 & 0.050 & 0.087 & 0.043 & 0.044 & 0.018 & 0.016 & 0.022 & 0.068 & 0.051 & 0.199 & 0.011 & 0.143 & 0.076 & 0.066 & 0.080 & 0.085 \\
\hline$V^{-}$ & 0.024 & 0.041 & 0.054 & 0.047 & 0.020 & 0.021 & 0.013 & 0.014 & 0.073 & 0.036 & 0.089 & 0.010 & 0.090 & 0.049 & 0.064 & 0.068 & 0.054 \\
\hline
\end{tabular}

TABLE 8: Environmental performance of suppliers.

\begin{tabular}{lccccc}
\hline Suppliers & $S_{i}^{-}$ & $S_{i}^{+}$ & $\bar{C}_{i}$ & Ranking & Class \\
\hline S1 & 0.02296 & 0.00382 & 0.85747 & 6 & $\mathrm{~B}$ \\
S2 & 0.01670 & 0.00297 & 0.84877 & 7 & $\mathrm{~B}$ \\
S3 & 0.01376 & 0.01685 & 0.44958 & 14 & $\mathrm{D}$ \\
S4 & 0.00961 & 0.02152 & 0.30866 & 16 & $\mathrm{D}$ \\
S5 & 0.02790 & 0.00572 & 0.82987 & 9 & $\mathrm{~B}$ \\
S6 & 0.02233 & 0.01026 & 0.68508 & 13 & $\mathrm{C}$ \\
S7 & 0.00835 & 0.02886 & 0.22442 & 17 & $\mathrm{D}$ \\
S8 & 0.03235 & 0.00385 & 0.89367 & 5 & $\mathrm{~B}$ \\
S9 & 0.04175 & 0.00223 & 0.94931 & 2 & $\mathrm{~A}$ \\
S10 & 0.01293 & 0.01889 & 0.40646 & 15 & $\mathrm{D}$ \\
S11 & 0.02717 & 0.00712 & 0.79237 & 10 & $\mathrm{~B}$ \\
S12 & 0.04153 & 0.00206 & 0.95268 & 1 & $\mathrm{~A}$ \\
S13 & 0.00535 & 0.03106 & 0.14704 & 18 & $\mathrm{D}$ \\
S14 & 0.03673 & 0.00366 & 0.90931 & 4 & $\mathrm{~A}$ \\
S15 & 0.03815 & 0.00290 & 0.92946 & 3 & $\mathrm{~A}$ \\
S16 & 0.02451 & 0.00994 & 0.71145 & 12 & $\mathrm{C}$ \\
S17 & 0.02824 & 0.00504 & 0.84861 & 8 & $\mathrm{~B}$ \\
S18 & 0.02756 & 0.00734 & 0.78955 & 11 & $\mathrm{~B}$ \\
\hline
\end{tabular}

other industries. Evaluation criteria can be changed from one sector to an other. Appropriate evaluation criteria of green performance should be selected according to the sector.
TABLE 9: Classification scale.

\begin{tabular}{lcl}
\hline $\bar{C}$ & Class & Definition \\
\hline $0.900-1.000$ & A & Environmental performance is perfect \\
$0.700-0.899$ & B & $\begin{array}{l}\text { Environmental performance is good } \\
\text { Environmental performance is inadequate. }\end{array}$ \\
$0.500-0.699$ & C & $\begin{array}{l}\text { It needs improvements } \\
\text { Environmental performance is bad. It has to } \\
\text { be certainly developed }\end{array}$ \\
\hline
\end{tabular}

Therefore, the green supply chain that is already a hot topic could become the new trend of the future.

\section{References}

[1] A. H. I. Lee, H. Y. Kang, C. F. Hsu, and H. C. Hung, "A green supplier selection model for high-tech industry," Expert Systems with Applications, vol. 36, pp. 7917-7927, 2009.

[2] R. J. Kuo, Y. C. Wang, and F. C. Tien, "Integration of artificial neural network and MADA methods for green supplier selection," Journal of Cleaner Production, vol. 18, no. 12, pp. 1161-1170, 2010.

[3] S. Vachon and R. D. Klassen, "Green project partnership in the supply chain: the case of the package printing industry," Journal of Cleaner Production, vol. 14, no. 6-7, pp. 661-671, 2006. 
[4] G. Noci, "Designing "green" vendor rating systems for the assessment of a supplier's environmental performance," European Journal of Purchasing and Supply Management, vol. 3, no. 2, pp. 103-114, 1997.

[5] G. Büyüközkan and G. Çiftçi, "A novel hybrid MCDM approach based on fuzzy DEMATEL, fuzzy ANP and fuzzy TOPSIS to evaluate green suppliers," Expert Systems with Applications, vol. 39, no. 3, pp. 3000-3011, 2012.

[6] D. G. Li, Z. Y. Zhou, and C. Yang, "A model on supplier selection in Green Supply chain based on HP Neural network," Applied Mechanics and Materials, vol. 143-144, pp. 312-327, 2012.

[7] R. Handfield, S. V. Walton, R. Sroufe, and S. A. Melnyk, "Applying environmental criteria to supplier assessment: a study in the application of the analytical hierarchy process," European Journal of Operational Research, vol. 141, no. 1, pp. 70-87, 2002.

[8] L. Y. Y. Lu, C. H. Wu, and T. C. Kuo, "Environmental principles applicable to green supplier evaluation by using multi-objective decision analysis," International Journal of Production Research, vol. 45, no. 18-19, pp. 4317-4331, 2007.

[9] P. Rao and D. Holt, "Do green supply chains lead to competitiveness and economic performance?" International Journal of Operations and Production Management, vol. 25, no. 9, pp. 898916, 2005.

[10] G. Tuzkaya, A. Ozgen, D. Ozgen, and U. R. Tuzkaya, "Environmental performance evaluation of suppliers: a hybrid fuzzy multi-criteria decision approach," International Journal of Environmental Science and Technology, vol. 6, no. 3, pp. 477-490, 2009.

[11] W. H. Tsai and S. J. Hung, "A fuzzy goal programming approach for green supply chain optimisation under activity-based costing and performance evaluation with a value-chain structure," International Journal of Production Research, vol. 47, no. 18, pp. 4991-5017, 2009.

[12] C. Bai and J. Sarkis, "Green supplier development: analytical evaluation using rough set theory," Journal of Cleaner Production, vol. 18, no. 12, pp. 1200-1210, 2010.

[13] A. Awasthi, S. S. Chauhan, and S. K. Goyal, "A fuzzy multicriteria approach for evaluating environmental performance of suppliers," International Journal of Production Economics, vol. 126, no. 2, pp. 370-378, 2010.

[14] X. Fu, Q. Zhu, and J. Sarkis, "Evaluating green supplier development programs at a telecommunications systems provider," International Journal of Production Economics, vol. 140, no. 1, pp. 357-367, 2012.

[15] V. Baskaran, S. Nachiappan, and S. Rahman, "Indian textile suppliers' sustainability evaluation using the grey approach," International Journal of Production Economics, vol. 135, no. 2, pp. 647-658, 2012.

[16] K. Shaw, R. Shankar, S. S. Yadav, and L. S. Thakur, "Supplier selection using fuzzy AHP and fuzzy multi-objective linear programming for developing low carbon supply chain," Expert Systems with Applications, vol. 39, pp. 8182-8192, 2012.

[17] T. L. Saaty, Decision Making with Dependence and Feedback: The Analytic Network Process, RWS Publications, Pittsburgh, Pa, USA, 2nd edition, 2001.

[18] K. Green, B. Morton, and S. New, "Purchasing and environmental management: interaction. policies and opportunities," Business Strategy and the Environment, vol. 5, pp. 188-197, 1996.

[19] S. K. Srivastava, "Green supply-chain management: a state-ofthe-art literature review," International Journal of Management Reviews, vol. 9, no. 1, pp. 53-80, 2007.
[20] E. U. Olugu, K. Y. Wong, and A. M. Shaharoun, "Development of key performance measures for the automobile green supply chain," Resources, Conservation and Recycling, vol. 55, no. 6, pp. 567-579, 2011.

[21] A. A. Hervani, M. M. Helms, and J. Sarkis, "Performance measurement for green supply chain management," Benchmarking, vol. 12, no. 4, pp. 330-353, 2005.

[22] B. Rettab and A. Ben Brik, Green Supply Chain in Dubai, Dubai Chamber Centre for Responsible Business Dubai, Dubai, UAE, 2008.

[23] R. Narasimhan and J. R. Carter, Environmental Supply Chain Management, The Center for Advanced Purchasing Studies, Arizona State University, Tempe, Ariz, USA, 1998.

[24] J. D. Linton, R. Klassen, and V. Jayaraman, "Sustainable supply chains: an introduction," Journal of Operations Management, vol. 25, no. 1, pp. 1075-1082, 2007.

[25] R. Handfield, R. Sroufe, and S. Walton, "Integrating environmental management and supply chain strategies," Business Strategy and the Environment, vol. 14, no. 1, pp. 1-19, 2005.

[26] J. Hall, "Environmental supply chain dynamics," Journal of Cleaner Production, vol. 8, no. 6, pp. 455-471, 2000.

[27] Q. Zhu, J. Sarkis, and K.-H. Lai, "Confirmation of a measurement model for green supply chain management practices implementation," International Journal of Production Economics, vol. 111, no. 2, pp. 261-273, 2008.

[28] T. Wu, D. Shunk, J. Blackhurst, and R. Appalla, "AIDEA: a methodology for supplier evaluation and selection in a supplierbased manufacturing environment," International Journal of Manufacturing Technology and Management, vol. 11, no. 2, pp. 174-192, 2007.

[29] S. R. Gordon, "Supplier evaluation: benefits, barriers and best practices," in Proceedings of the 91st Annual International Supply Management Conference, May 2006.

[30] P. K. Humpreys, Y. K. Wong, and F. T. S. Chan, "Integrating environmental criteria into the supplier selection process," Journal of Materials Processing Technology, vol. 138, pp. 349-356, 2003.

[31] P. Humphreys, R. McIvor, and F. Chan, "Using case-based reasoning to evaluate supplier environmental management performance," Expert Systems with Applications, vol. 25, no. 2, pp. 141-153, 2003.

[32] C. W. Hsu and A. H. Hu, "Applying hazardous substance management to supplier selection using analytic network process," Journal of Cleaner Production, vol. 17, pp. 255-264, 2009.

[33] T. L. Saaty, "Decision making-the analytic hierarchy and network processes (AHP/ANP)," Journal of Systems Science and Systems Engineering, vol. 13, no. 1, pp. 1-34, 2004.

[34] W. H. Tsai and W. C. Chou, "Selecting management systems for sustainable development in SMEs: a novel hybrid model based on DEMATEL, ANP, and ZOGP," Expert Systems with Applications, vol. 36, no. 2, pp. 1444-1458, 2009.

[35] C. L. Lin, M. S. Hsieh, and G. H. Tzeng, "Evaluating vehicle telematics system by using a novel MCDM techniques with dependence and feedback," Expert Systems with Applications, vol. 7, no. 10, pp. 6723-6736, 2010.

[36] E. Manokaran, S. Subhashini, S. Senthilvel, R. Muruganandham, and K. Ravichandran, "Application of multi criteria decision making tools and validation with optimization techniquecase study using TOPSIS, ANN \& SAW,' International Journal of Management \& Business Studies, vol. 1, no. 3, pp. 112-115, 2011. 
[37] M. T. Chu, J. Shyu, G. H. Tzeng, and R. Khosla, “Comparison among three analytical methods for knowledge communities group-decision analysis," Expert Systems with Applications, vol. 33, no. 4, pp. 1011-1024, 2007.

[38] G. R. Jahanshahloo, F. H. Lotfi, and M. Izadikhah, "An algorithmic method to extend TOPSIS for decision-making problems with interval data," Applied Mathematics and Computation, vol. 175, no. 2, pp. 1375-1384, 2006.

[39] E. Öz and F. Ö. Baykoç, “Tedarikçi seçimi problemine karar teorisi destekli uzman sistem yaklasımı," Journal of the Faculty of Engineering and Architecture of Gazi University, vol. 19, no. 3 , pp. 275-286, 2004.

[40] A. G. Abdul-Mumin, "Instrumental and interpersonal determinants of relationship satisfaction and commitment in industrial markets," Journal of Business Research, vol. 58, pp. 619-628, 2005.

[41] L. Shenc, L. Olfat, K. Govindan, R. Khodaverdia, and A. Diabat, "A fuzzy multi criteria approach for evaluating green supplier's performance in green supply chain with linguistic preferences," Resources, Conservation and Recycling, 2012.

[42] G. Azzone and G. Noci, "Measuring the environmental performance of new products: an integrated approach," International Journal of Production Research, vol. 3, no. 11, pp. 3055-3078, 1996.

[43] Q. Zhu and J. Sarkis, "Relationships between operational practices and performance among early adopters of green supply chain management practices in Chinese manufacturing enterprises," Journal of Operations Management, vol. 22, no. 3, pp. 265-289, 2004. 

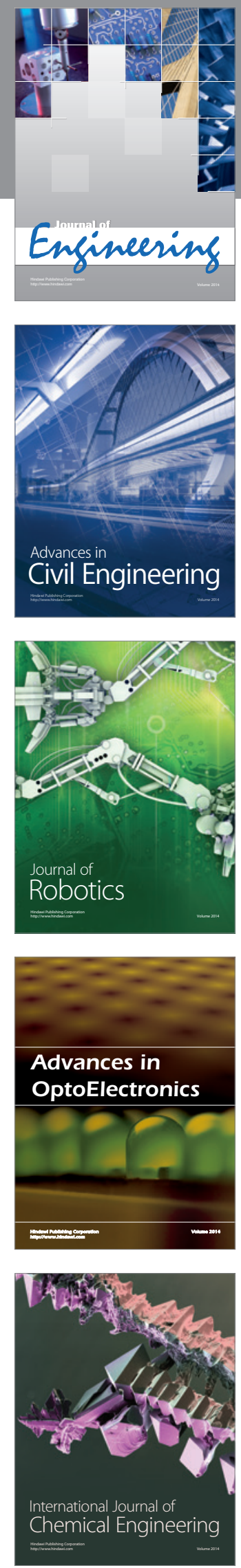

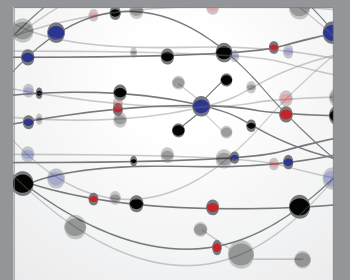

The Scientific World Journal
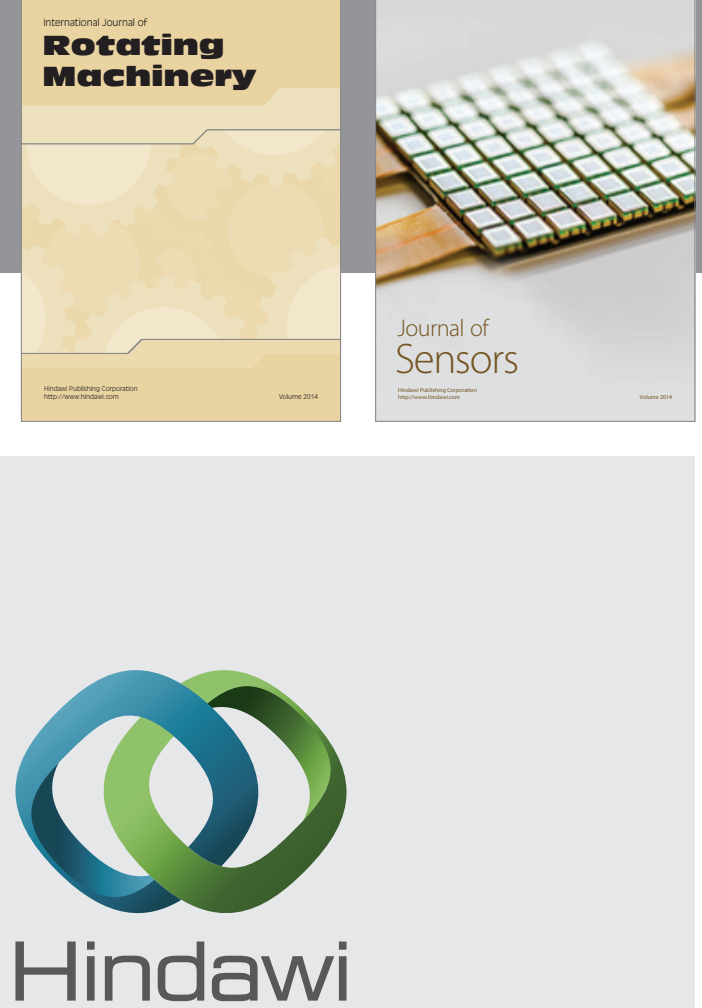

Submit your manuscripts at http://www.hindawi.com
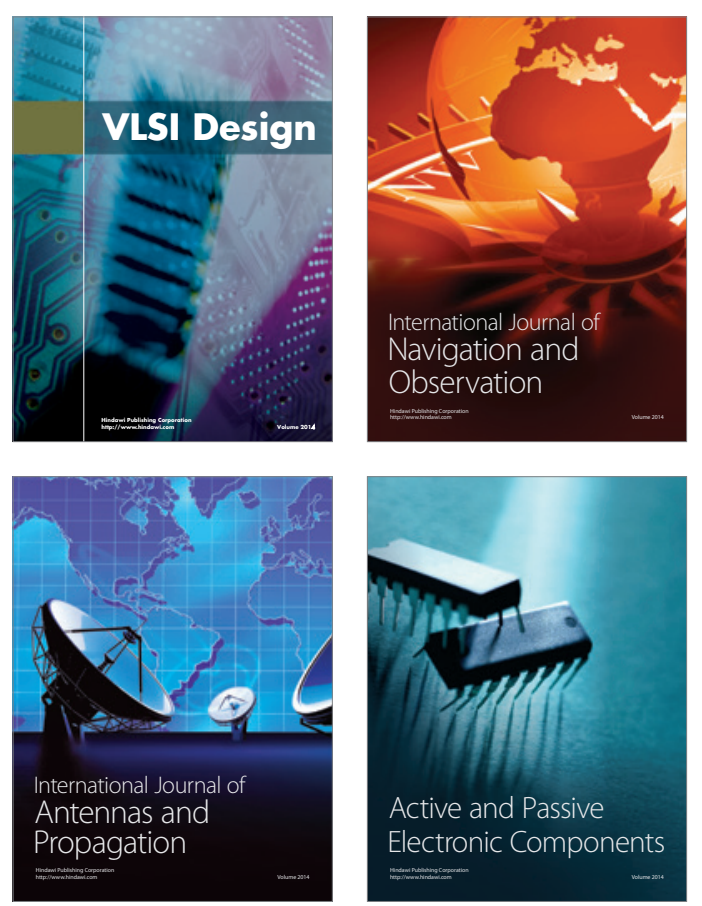
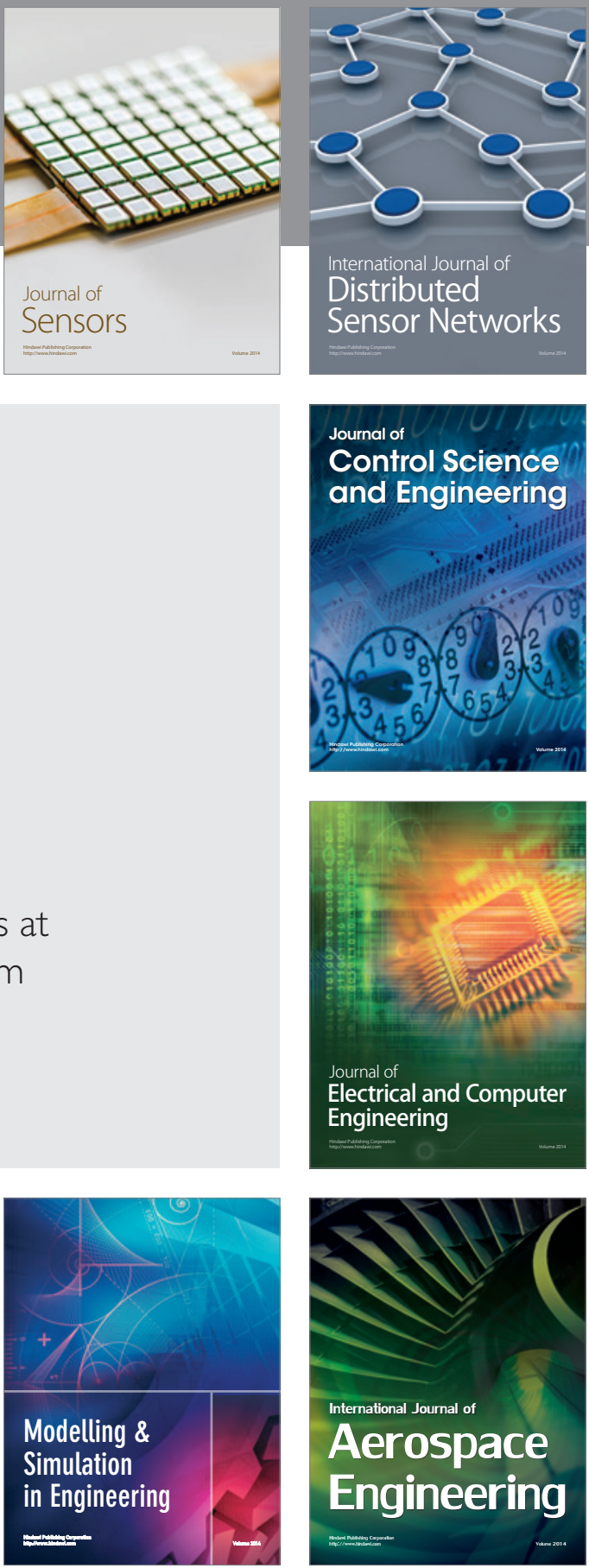

Journal of

Control Science

and Engineering
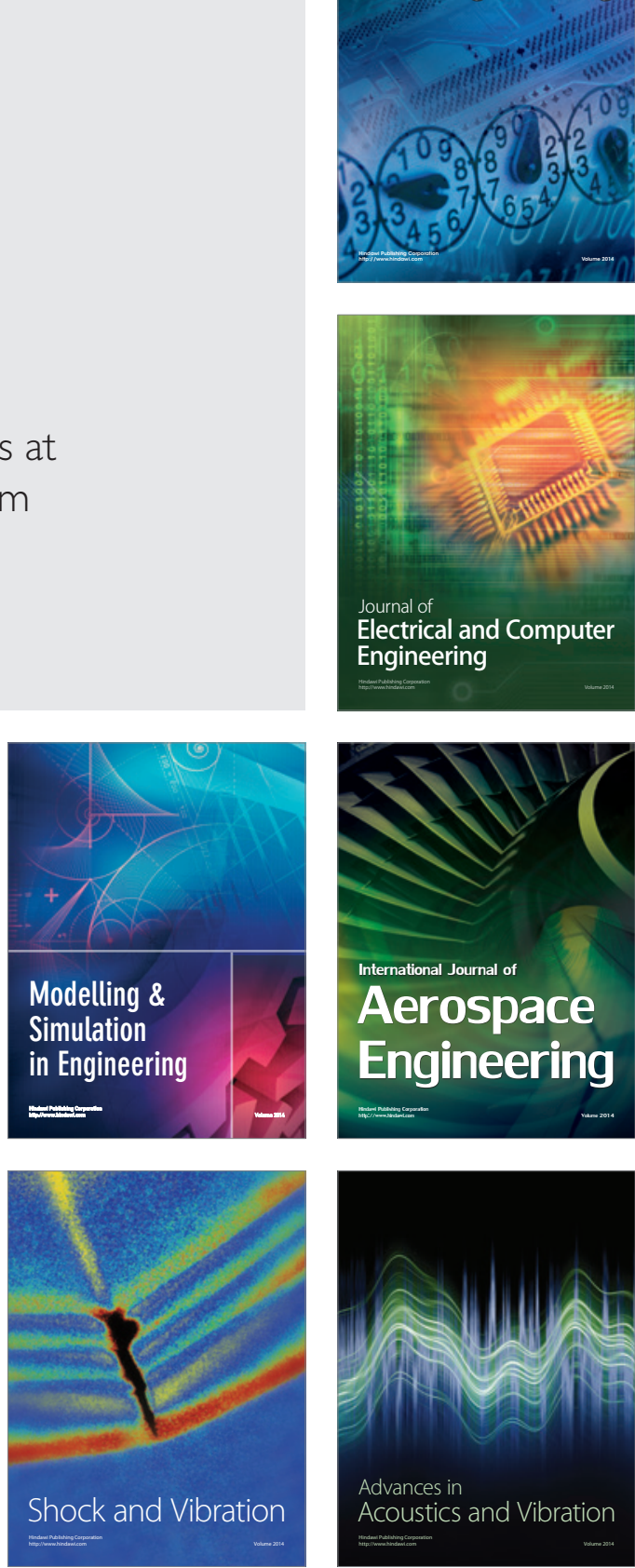